\author{
Shash N.N. ${ }^{1}$, Pshembayeva D. ${ }^{2}$ \\ ${ }^{1}$ Doctor of Economic Sciences, Professor, Plekhanov Russian University of Economics, \\ Russia, Moscow, e-mail: nat vshu@mail.ru \\ ${ }^{2}$ doctoral student, Kazakh humanitarian-law innovative university, \\ Kazakhstan, Semey, e-mail: b.sydyk@yandex.ru

\section{NEW PARADIGM OF TOURISM INDUSTRY MODERNIZATION IN THE DIGITAL ECONOMY CONDITIONS}

The article discusses the modern features of the tourism industry, its role and importance in the country's economy, the quantitative and qualitative changes that take place in this area, including the number of employees, average wages, investments, the degree of depreciation of fixed assets of tourist organizations. The article analyzes the current information state of development of the tourism industry, considers the meaningful change in business processes in tourism when introducing new information and communication technologies, shows that in the digital economy, information becomes the key and determining factor in the development of tourism activities. It is shown that in tourism the main element in the formation of tourist services is information that is consonant with the modern paradigm of the digital economy. The statistics of the development of the information and communication technology sector, which provides opportunities for the functioning of the digital economy, is presented. The characteristic of the information space of the tourism industry, the latest digital technologies that are beginning to be used in the tourism industry is given.

Key words: tourism industry, digital economy, tourism ecosystem, digital technologies, information and communications technologies.

\author{
Шаш Н.Н. ${ }^{1}$, Пшембаева $\Delta .{ }^{2}$ \\ 'э.ғ.А., профессор, Плеханов атындағы Ресей экономикалық, университеті, \\ Ресей, Мәскеу к., e-mail: nat vshu@mail.ru \\ ${ }^{2}$ Аокторант, Қазақ инновациямық гуманитарлық-заң университеті, \\ Қазақстан, Семей к., e-mail: b.sydyk@yandex.ru \\ Цифрлық экономика жағдайында \\ туризм саласын жаңғыртудың жаңа парадигмасы
}

Мақалада туризм саласының қазіргі заманғы ерекшеліктері, оның ел экономикасындағы рөлі
мен маңызы, осы салада болып жатқан сандық, және сапалық өзгерістер, соның ішінде жұмыспен
қамтылғандар саны, орташа жалақы, салынған инвестициялар, туристік ұйымдардың негізгі
қорларының тозу дәрежесі бойынша қарастырылған. Мақалада туристік индустрияны
дамытудың қазіргі заманғы ақпараттық, жай-күйіне талдау жүргізілген, жаңа ақпараттық-
коммуникациялық, технологияларды енгізу кезінде туризм саласындағы бизнес-процестердің
мазмұнды өзгеруі қарастырылған, сандық, экономика жағдайында ақпарат туристік қызметті
дамытудың негізгі және айқындаушы факторына айналатыны көрсетілген. Туристік қызметтерді
қалыптастырудағы негізгі элемент - сандық экономиканың қазіргі парадигмасына сәйкес келетін
ақпарат екендігі көрсетілген. Цифрлық, экономиканың жұмыс істеу мүмкіндігін қамтамасыз
ететін ақпараттық-коммуникациялық технологиялар секторының даму статистикасы ұсынылған.
Туризм индустриясында қолданылатын жаңа сандық технологиялар, туризм индустриясының
ақпараттық кеңістігінің сипаттамасы берілген.

Түйін сөздер: туризм саласы, цифрлық экономика, туризм экожүйесі, цифрлық технологиялар, ақпараттық, және коммуникациялық, технологиялар. 


\author{
Шаш Н.Н. ${ }^{1}$, Пшембаева $\Delta .{ }^{2}$ \\ ${ }^{1}$ А.э.н., профессор, Росссийский экономический университет им. Плеханова, \\ Россия, г. Москва, e-mail: nat vshu@mail.ru \\ ${ }^{2}$ Аокторант, Казахский гуманитарно-юридический инновационный университет, \\ Казахстан, г. Семипалатинск, e-mail: b.sydyk@yandex.ru
}

Новая парадигма модернизации отрасли туризма в условиях цифровой экономики

\begin{abstract}
В статье рассмотрены современные особенности сферы туризма, ее роль и значение в экономике страны, количественные и качественные изменения, протекающие в этой сфере, в том числе по численности занятых, средней заработной плате, вкладываемых инвестициях, степени износа основных фондов туристических организаций. В статье проведен анализ современного информационного состояния развития туристской индустрии, рассмотрено содержательное изменение бизнес-процессов в туризме при внедрении новых информационно-коммуникационных технологий, показано, что в условиях цифровой экономики информация становится ключевым и определяющим фактором развития туристской деятельности. Показано, что в туризме основным элементом при формировании туристских услуг выступает информация, что созвучно современной парадигме цифровой экономики. Представлена статистика развития сектора информационно-коммуникационных технологий, который обеспечивает возможности функционирования цифровой экономики. Аана характеристика информационного пространства индустрии туризма, новейших цифровых технологий, которые начинают применяться в индустрии туризма.
\end{abstract}

Ключевые слова: отрасль туризма, цифровая экономика, экосистема туризма, цифровые технологии, информационные и коммуникационные технологии.

\section{Introduction}

The level of tourism and service development is one of the parameters that characterize the socioeconomic development of countries and the degree of well-being of the population (Seetanah, 2011). Tourism is actively developing in those countries where the income level of the population is high enough and the need to maintain and restore the health of the nation is formed. Tourism is not only the largest, but also the fastest growing sector of the world economy, the growth rate of which is almost 2 times higher than the growth rate of other sectors of the economy. In terms of key indicators, including the effectiveness of investments, tourism is comparable to the oil industry. The tourism industry accounts for about $10 \%$ of the world total product, $30 \%$ of world exports of services, $7 \%$ of world investments, $10 \%$ of jobs, and $5 \%$ of all tax revenues (WTTC, 2018). Tourism has become the most important area of economic activity for the world economy as a whole, and for the national economies of many countries.

In addition, tourism and the hospitality industry are an information-rich field where the collection, transmission and processing of digital information are of great importance in making decisions at all levels of tourism management. Technological advances have already had a significant impact on how the tourism industry does business. The Internet has become a key source of information for tourists, giving them the opportunity to receive information both directly from destinations and travel agents, as well as from individual passengers through social networks, blogs and websites that provide various useful travel information. The development of digital technologies forms the main trends in the development of the global tourism industry market in the world, including in Kazakhstan.

The President of the Republic of Kazakhstan, N. Nazarbayev, in his traditional annual Address to the Nation of Kazakhstan on January 10, 2018, "New Development Opportunities in the Context of the Fourth Industrial Revolution" (Nazarbayev, 2018), pays special attention to ubiquitous digitalization. Kazakhstan within the framework of the State Program "Digital Kazakhstan" (State program "Digital Kazakhstan", 2017) plans to introduce information technologies in five main areas: digitalization of economic sectors, transition to a digital state, implementation of a digital silk road, development of human capital, creation of an innovation ecosystem. At the present time, there is no any integrated application or platform in the tourist market of the Republic of Kazakhstan that could fully provide visitors of the country, as well as domestic tourists with all the necessary information. Currently, tour operators offer almost identical tour packages (visiting the most famous sights). At the same time, it is necessary to expand the range of 
offers and increase information accessibility with the help of more creative, innovative solutions, which allows an increase in the number of repeated trips and visits. The above carries a very important message for Kazakhstan, namely: it is necessary immediately begin developing a professional national Internet platform, integrating into it the key marketing and booking functions, and start promoting it on the international market as part of the country's national marketing strategy.

The purpose of this article is to form a new paradigm of tourism industry modernization, as well as a detailed analysis of digital tourism zones and the development of destination potential in the digital economy conditions.

\section{Literature review}

An analysis of recent research and publications has shown that the work of domestic and foreign researchers is devoted to the study of the essence of digital transformation. So, in the research of Ardolino et al. (2018) reviewed the role of digital technologies for the service transformation of industrial companies. Korpela et al. (2017) explain how supply chain integration through the blockchain technology can achieve disruptive transformation in digital supply chains and networks. Al-Sai \& Abualigah (2017) in their research explore a review in big data issues that applied to e-government as well as challenges and issues facing these agencies and proposed a possible solution for the challenges of implementing big data in e-government. The problems of digital transformation in financial services are reviewed in the research of Scardovi (2017). The research of Luna-Reyes, \& Gil-Garcia (2014) present a theory of the co-evolution of technology, organizational networks, and institutional arrangements in the transformation of government. Authors as Yakushenko \& Shimanskaya (2017) substantiate the need for digital transformation of information support for economic management, as well as consider examples of the development of digital technologies in various fields of activity. Ziyadin et al. (2019) note the need for accelerated technological modernization through the cultivation and introduction of new industries, the development of industrial and tourist infrastructure. In the research work of Watkins et al. (2018) examines the impact of digital development on the tourism industry. It also considers the advantages of information technology in the promotion of etourism. In the research work of Xiang (2018) presents an overview of the research development over the last twenty years on information technology and tourism. It argues that knowledge created in the last two decades can be characterized as consisting of two distinct eras, i.e., Digitization (1997-2006) and Age of Acceleration (2007-2016), which reflected the general understanding of how technology has transformed our society and economy. In the research paper of Benyon et al. (2014) provides an introduction to digital tourism as mediated by presence research as a means to create substantive user experiences (UX) for visitors. The research paper of Ch'ng (2011) focuses on new media-enhanced exploration and learning of culture and heritage. It aims to bridge the continuity of the visitor experience prior to, during, and after the visit, tools for urban heritage managers and how data from the continuity of tourist information processing may be used for planning and sustainable development of heritage sites. Despite the presence of scientific interest in the research as a whole, currently the unresolved part is the problem of forming a new paradigm of tourism industry modernization in the digital economy conditions. On this basis, there is a need for a more detailed study of the essence of digital transformation in modern tourism activities and the identification of its main trends, since the lack of knowledge and lack of systematization of directions creates certain difficulties in the process of developing strategy.

The aviation, travel and tourism industry has been at the forefront of digital innovation, but industry and technology trends suggest that further change lies ahead. The sector has been an early adopter of digital technologies and platforms, but steep demand for travel, driven by a growing middle class in emerging markets and the increasing importance of digital experiences, implies that further digitalization will be vital if the expectations of tomorrow's consumers are to be met. Four themes have been identified that will take center stage in shaping travel and tourism over the next decade:

1. Living travel experience. Travelers will experience seamless journeys tailored to their habits and preferences. Companies along the Aviation, Travel and Tourism industry journey will optimize customer experience by collecting and exchanging data, and continuously generating insights. In time, travel will become frictionless, blending seamlessly with other everyday activities.

2. Enabling the travel ecosystem. Ecosystem roles are blurring as stakeholders throughout the customer journey vie to own the customer 
relationship. Digital platforms that enable ecosystem alliances will continue to emerge, as asset and information sharing become increasingly important from a B2B perspective.

3. Digital enterprise. Digital technologies that revolutionize manufacturing, optimize the real-time use of assets and eventually augment the industry workforce will transform operations. Innovations such as 3D printing, AI, the Internet of Things (IoT), virtual reality (VR) and digital platforms will enable flexible working and changes to core operational processes.

4. Safety and security. As identity management becomes increasingly digital, a collaborative effort towards boosting cybersecurity and protecting the privacy of traveller data will be crucial to maintaining customer trust and public safety. Digital technologies (e.g. biometrics such as facial recognition, IoT, crowd analytics and video monitoring via AI) will be used to create a ubiquitously secure environment (Weinelt, \& Moavenzadeh, 2017).

Information support of tourism is a set of information database on tourism activities and specialized information technologies intended for its processing, which ensure the effective functioning of the tourism system (Gretzel, 2015). The travel ecosystem (Figure 1) has helped shape customer expectations for on-demand and convenient services through digital innovation, both within and across industry boundaries. The next step is for organizations that are lagging to change how they work, so that they too can capture the opportunities that digital transformation presents.

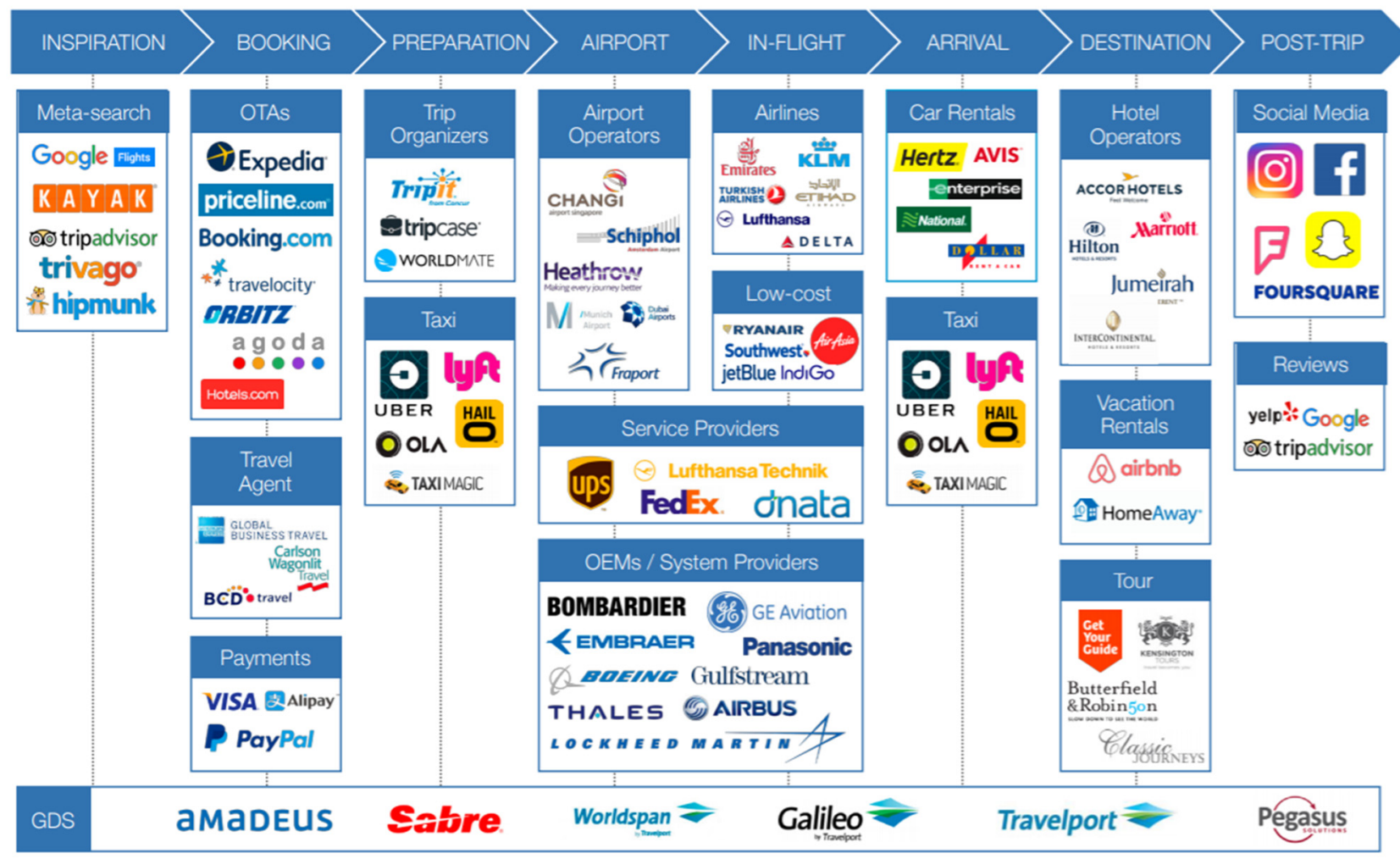

Figure 1 - The Aviation, Travel and Tourism Ecosystem Source: Spelman, 2017

The transformation is encapsulated in a macro trend: from the traditional economy to the new economy, i.e. from manufacturing to services. Digital is one of the developments that enables companies to offer services instead of products. As an industry, aviation, travel and tourism has a head start, because of its position as a heavily serviceoriented ecosystem at the "digital economy" end of the spectrum (Weinelt, \& Moavenzadeh, 2017). 


\section{Methodology}

Kazakhstan, having rich touristic and recreational potential, is characterized by an unfortunately inadequate level of touristic development.

According to the index of competitiveness of travel and tourism, Kazakhstan in 2017 ranked $81^{\text {st }}$ out of 136 countries, and in $2015-85^{\text {th }}$ of 141 countries. Kazakhstan improved its position by four spots to $81^{\text {st }}$ in the latest World Economic Forum's (WEF) Travel \& Tourism Competitiveness Index (Figure 2). The index is published biannually and compares 136 economies on factors and policies enabling sustainable travel and tourism development, which contributes to the development and competitiveness of a country, according to the WEF report (WEF, 2017).

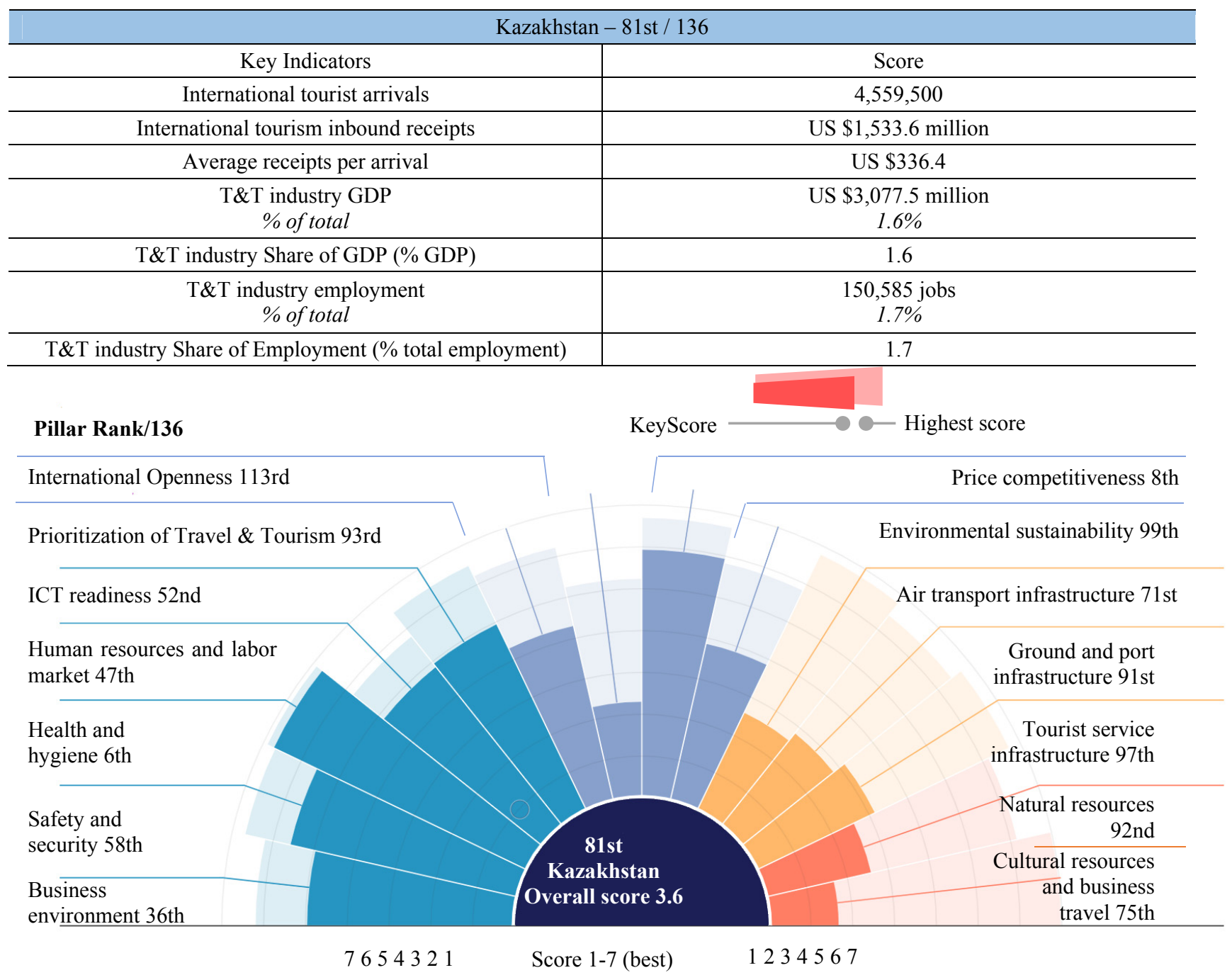

Figure 2 - Travel and Tourism Competitiveness Index of Kazakhstan Source: WEF, 2017

Kazakhstan's information and communications technologies (ICT) readiness was ranked $52^{\text {nd }}$. The report shows that within the tourist service infrastructure pillar, quality of tourist infrastructure and the presence of major car rental companies has a negative impact int this regard. In the Eurasian region, Kazakhstan is in fourth place after Russia (43 $3^{\text {rd }}$ in the global rank), Georgia (70) and Azerbaijan (71). The country was followed by Armenia (84), Tajikistan (107) and the Kyrgyz Republic (115). Its share in the gross domestic product (calculated for accommodation and food 
services only) in 2015 is about $0.3 \%$, and the gross added value created directly in tourism was 406.4 billion KZT, or $1.0 \%$, of Kazakhstan's GDP, which is a relatively low index. For comparison, the contribution of the tourism sector to the Turkish GDP is $10.9 \%$, whilst in the UAE GDP is $14.3 \%$. In 2016 , the number of employees in the tourism sector was 43.7 thousand people (WEF, 2017).

The online travel market is developing rapidly all over the world and is estimated at $\$ 300$ billion. However, if at least $60 \%$ of tickets in the US are sold online, in Europe at least $50 \%$, in Kazakhstan it is no more than $8-10 \%$. Today travel is much easier than, say, 10-15 years ago. Hotels, flights, travel programs, car rental and even a table in a restaurant can be booked worldwide using reservation systems, that is, online. According to statistics of the National Bank of Kazakhstan, in 2013 the volume of online payments amounted to 265.4 billion KZT. Growth compared with $2012-81.5 \%$ (119.2 billion KZT). At the same time, the share of tourism from the total amount of all Internet payments does not exceed 1\%.

Kazakhstan currently occupies the 90th place in the WEF rating on the use of information and communication technologies, which is also associated with the low activity of the business environment for the introduction of new technologies in its work, including in the tourism sector (innovative activity of the business is 7\%). Thus, the support of participants in the tourist industry in technological development and assistance in the digitalization of the industry can give a significant impetus to the development of domestic and inbound tourism by increasing the awareness of potential tourists about the tourist offers and the convenience and simplicity of the booking process and purchase of tour packages.

World Tourism Barometer - the analytical center of the World Tourism Organization - shows that in 2017 over 1.3 billion international travels were made. This is $7 \%$ more than in the previous year. Skift information platform experts agree: 2018 will be marked by the personalization of online travel via artificial intelligence, VR and digital assistants. According to the forecast of the international research agency IDC, by 2020 revenues from the implementation of cognitive technologies and artificial intelligence systems will exceed \$ 46 billion. For comparison, in 2017 they amounted to $\$ 12.5$ billion. In the tourism business, the demand for them is great, and the benefits are undoubted: data sets increase to alarming proportions and become not a competitive advantage, but a burden. Customers still prefer a personal or seeming appeal. According to Inter Globe Technologies, which manages business processes in the travel industry, personalized offers on online travel agency sites (OTA) push $50 \%$ of users to purchase.

The Republic of Kazakhstan has the following problems associated with creating a convenient information environment for tourists:

- absence or underdevelopment of basic physical infrastructure (signs, parking, additional services, accommodation, etc.);

- low level of integration of modern tourism technologies and low digitization;

- low level of awareness and knowledge of real tourist funds of the country (data, information, etc.);

- lack of a holistic tourist product from all available tourist segments (each works in isolation);

- the lack of a common tourism identity in the country, as well as a unified vision in the private sector.

The above carries a very important message for Kazakhstan, namely: you must immediately begin to develop a professional national Internet platform, integrating key marketing and booking functions into it, and start promoting it on the international market as part of the country's national marketing strategy.

One of the most important positive effects of tourism on the economy of the host destination is expressed in the multiplication effect or multiplier effect. The multiplicative effect of tourism is manifested in the process of the growing demand for the consumption of tourist services, causing the development of many related tourist activities, industries in the territories visited by tourists.

Tourism multiplier is a numerical factor that shows how many times the gross regional product will increase or decrease as a result of an increase or decrease in tourist spending. It characterizes the difference between direct income and indirect income from tourism at the local, regional or national level. This means that the higher the tourist multiplier, the more successfully the economy of the tourist destination develops. In developed sustainable destinations, the multiplier is higher than, for example, in island destinations, which must import a significant amount of goods to serve tourists (Pisarevskii, 2014).

The multiplier of international tourism is inversely proportional to the propensity to acquire imported products. Accordingly, the less the propensity to consume foreign goods and services, 
the greater will be the multiplier. Relatively small changes in the expenses of foreign tourists may cause significant changes in the incomes of residents of tourist centers.

$$
\begin{gathered}
\text { Multiplier of international tourism }= \\
=\text { increase in incomes of local } \\
\text { residents / initial expenses of foreign tourists }
\end{gathered}
$$

To measure the final effect, you will need to enter the following notation: $E$ - initial expenses of foreign tourists in the country of temporary residence (expenses); In - income of domestic economic entities (internal income); $P_{n}$ - propensity to purchase domestic products (propensity to national products); $P_{i m}$ - propensity to purchase imported products (propensity to imports); $n$ - the number of cycles of multiplicative expansion; $k-$ the multiplier of international tourism (International tourism multiplier, Multiplier of international tourism).

If all the costs of foreign tourists, carried out in the tourist center, will be directed to the purchase of domestically produced products, then the amount of expenses will be fully the increase in income of local residents:

$$
E=\Delta I n
$$

In the second cycle, the amount of income of local residents will be reduced by the number of imported products in accordance with the tendency of consumers to purchase imported products: $P_{n} E$.

In the third cycle, the balance of funds circulating within the national economy will be reduced in a similar way and will be: $2 P_{n} E$; in the fourth $-3 P_{n} E$ etc.

The total increase in income of local residents as a result of expenses incurred by foreign tourists will amount to the estimated income.

$$
\Delta I n=E+\frac{E}{P_{n}}+\frac{E}{P_{n}^{2}}+\frac{E}{P_{n}^{3}}+\cdots+\frac{E}{P_{n}^{n}}
$$

The given expression is an infinitely decreasing geometric progression, therefore, equation (3) has the form:

$$
\Delta I n=\frac{E\left(1-P_{n}^{n}\right)}{1-P_{n}}
$$

Substituting the resulting expression (4) into formula (2), we get

$$
k=\frac{\Delta I n}{E}=\frac{E\left(1-P_{n}^{n}\right)}{\left(1-P_{n}\right)}=\frac{1-P_{n}^{n}}{1-P_{n}}
$$

For an infinitely decreasing geometric progression, the quantity $P_{n}$ where $\mathrm{n} \rightarrow 0$, therefore, can be neglected. As a result, the multiplier of international tourism takes the form:

$$
k=\frac{1}{1-P_{n}}=\frac{1}{P_{i m}}
$$

The multiplier of international tourism is a change in the incomes of local residents of the tourist center and the initial expenses of foreign tourists that caused this change in income. The multiplier shows how many times the income of local residents will increase with an increase in the cost of foreign tourists by one. The multiplier in its present form (5) is among the simple ones, because it is based on a very elementary model of the economy. This multiplier provides for the withdrawal of only the amount spent on the purchase of imported products by visiting tourists and local consumers, and manufacturers. In fact, the sequence of cycles may be attenuated due to withdrawals made in each cycle in the form of savings, taxes and other deductions (Watkins et al., 2018).

\section{Results and discussion}

The application of this method in practice demonstrates the wide possibilities for its use in investment design, especially in conditions of uncertainty and increased risk. This method is convenient for practical application in that it successfully correlates with other economicstatistical methods, as well as with game theory. In addition, it gives more optimistic estimates in comparison with other methods.

First, the basic statistical indicators of the Republic of Kazakhstan should be determined (Table 1). 
Shash N.N., Pshembayeva D.

Table 1 - Statistic base of income in RK for 2016-2017 years according for foreign tourists coming

\begin{tabular}{|l|c|c|c|}
\hline \multicolumn{1}{|c|}{ Indicators } & 2016 & 2017 & The change $(\Delta)$ \\
\hline $\begin{array}{l}\text { Income in the state budget of the Republic of Kazakhstan (KZT } \\
\text { million) }\end{array}$ & 9308485,2 & 11567692 & 2259206,3 \\
\hline Import (USD million) & 22566,6 & 27566,6 & 5000 \\
\hline Import (KZT million) & 7221312 & 8986712 & 1765399,6 \\
\hline Note - compiled by authors based on data of RK Agency for Statistics \\
\hline
\end{tabular}

As indicated in Table 2, import in KZT:

$22566,6 * 320=7221312$ KZT million (2016);

$27566,6 * 326=8987612 \mathrm{KZT}$ million (2017).

To determine the multiplier of international tourism, Pim should be found:

$$
P_{i m}=\frac{\Delta M}{\Delta Y}
$$

where Pim is the ultimate propensity to import, $\Delta M$ is the change in the volume of imports, and $\Delta Y$ is the change in the volume of national income in the previous period. The multiplier of international tourism is thus:

$$
k=\frac{1}{\frac{1765399,6}{2259206,3}}=1,28
$$

Some authors define this indicator as a multiplier of costs or revenues when the economic variable is the aggregate regional product or income, which is determined by the gross expenditure of travelers on the acquisition of goods and services (Watkins et al., 2018).

\section{Conclusion}

The development of the digital economy will drastically change the infrastructural support of many types of economic activity, including tourism, increasing the importance of the information component. Due to the fact that the digital economy is based on the ideology of processing large volumes of information, then a high-tech system will become particularly important for the safe, reliable, longterm storage of large amounts of information, as well as a subsystem for ensuring their security. In the conditions of the digital economy, social life and tourist activities are becoming more and more technologized, a single information space is being created in the field of world tourism, new principles of information support and tourism management are being formed. Information support of the tourist business and its digitalization are a strategic resource for enhancing the competitiveness of tourism. The current ecosystem of the tourism sector largely depends on access to the Internet, electronic transactions and services provided through the network, so the deployment and use of digital solutions is the basis for adaptation to business needs, both from the point of view of the user and service provider. This situation is like the situation in other sectors, but given the variety of intermediary schemes in tourism, here the need for its use is greater. This facilitates unified access to content, services, applications and tools, improves the efficiency of activities in the organization, simplifies the coordination of working groups and real-time interaction in projects, improves distance learning.

Among the main advantages of digital transformation for tourism is the deepening of knowledge of the traveler based on the analysis of the data obtained; reducing the time that must be allocated to inputs, outputs information, management and administrative processes; availability of smart payment mechanisms and payment by the client of only those services that it consumes. In other words, in the tourism industry, important trends in digital transformation have emerged, and the integration of these technologies into tourism products and services is a fundamental element of the innovation process leading to intelligent tourism. 


\section{References}

Al-Sai Z.A., Abualigah L.M. (2017) Big data and e-government: a review. $8^{\text {th }}$ International Conference on Information Technology (ICIT).

Ardolino M.R., Rapaccini M., Saccani N., Gaiardelli P., Crespi G., Ruggeri C. (2018) The role of digital technologies for the service transformation of industrial companies. International Journal of Production Research, vol. 6 (56), pp. 2116-2132.

Benyon D., Quigley A., O’Keefe B., Riva G. (2014) Presence and digital tourism. AI \& society, vol. 29(4), pp. 521-529.

Ch'ng E. (2011) Digital heritage tourism: Reconfiguring the visitor experience in heritage sites, museums and architecture in the era of pervasive computing. In Percorsi creative di turismo urbano (Creative Paths Of Urban Tourism) Conference, pp. 22-24. Gretzel U.S. (2015) Smart tourism: foundations and developments. Electronic Markets, vol. 3(25), pp. 179-188.

Korpela K., Hallikas J., Dahlberg T. (2017) Digital supply chain transformation toward blockchain integration. Proceedings of the 50th Hawaii international conference on system sciences.

Luna-Reyes L.F., Gil-Garcia J.R. (2014) Digital government transformation and internet portals: The co-evolution of technology, organizations, and institutions. Government information quarterly, vol. 31(4), pp. 545-555.

Ministry of national economy of the Republic of Kazakhstan Committee on statistics (2017) Tourism of Kazakhstan Statistical collection 2012-2016, http://stat.gov.kz/

Nazarbayev N. (2018). New opportunities under the fourth industrial revolution. State of the Nation Address by the President of the Republic of Kazakhstan, http://www.akorda.kz/en/addresses/addresses_of_president/state-of-the-nation-address-by-thepresident-of-the-republic-of-kazakhstan-nursultan-nazarbayev-january-10-2018.

Pisarevskii E.L. (2014) Osnovy turizma: uchebnik/kollektiv avtorov. M.: Federal'noe agentstvo po turizmu.

Scardovi C. (2017) Digital transformation in financial services. Springer.

Seetanah B. (2011) Assessing the dynamic economic impact of tourism for island economies. Annals of Tourism Research, vol. 38(1), pp. 291-308.

Spelman M.W. (2017) Digital Transformation Initiative Aviation, Travel and Tourism Industry. Geneva, Switzerland: World Economic Forum White Paper.

State program "Digital Kazakhstan", Resolution of the Government of the Republic of Kazakhstan dated December 12, 2017 № 827, http://adilet.zan.kz/rus/docs/P1700000827.

Watkins M., Ziyadin S., Imatayeva A., Kurmangalieva A., Blembayeva A. (2018) Digital tourism as a key factor in the development of the economy. Economic Annals-XXI, vol. 169(1-2), pp. 40-45.

Weinelt B., Moavenzadeh J. (2017) Digital Transformation Initiative: Aviation, Travel and Tourism Industry. In Geneva, Switzerland: World Economic Forum.

World Tourism Organization (UNWTO) (2017) UNWTO Tourism Highlights, https://www.e-unwto.org/

World Travel \& Tourism Council (2018) Travel \& Tourism Economic Impact 2018. The Harlequin Building, 65 Southwark Street, London SE1 0HR, United Kingdom: The autority on world travel \& tourism.

Xiang Z. (2018) From digitization to the age of acceleration: On information technology and tourism. Tourism management perspectives, vol. 25, pp. 147-150.

Yakushenko K.V. (2017) Tsifrovaya transformatsiya informatsionnogo obespecheniya upravleniya ekonomikoy gosudarstvchlenov EAES. Novosti nauki i tekhnologiy, vol. 2, pp. 11-20.

Ziyadin S., Litvishko O., Dubrova M., Smagulova G., Suyunchaliyeva M. (2019) Diversification tourism in the conditions of the digitalization. International Journal of Civil Engineering and Technology, vol. 10(2), pp. 1055-1070. 